\title{
Production of red wine from roselle (Hibiscus sabdariffa) and pawpaw (Carica papaya) using palm-wine yeast (Saccharomyces cerevisiae)
}

\author{
Okoro, Casmir Emeka* \\ Department of Food Technology, \\ Yaba College of Technology, \\ Yaba-Lagos. \\ *Address for correspondence, E-mail :emoko102003@yahoo.com
}

ABSTRACT

\begin{abstract}
Red wine was produced from must formulated by mixing $10 \%(\mathrm{w} / \mathrm{v})$ roselle calyces (Hibiscus sabdriffa var. sabdariffa) Hot water extract with pawpaw juice at the rate of $3: 1$. The must was formulated using a pure strain of Sacchromyces cerevisiae isolated from palm wine, propagated and pitched at a rate of $8 \%(\mathrm{v} / \mathrm{v})$. The must had a $\mathrm{pH}$ of 3.76 and a specific gravity of $22 \%(\mathrm{w} / \mathrm{w})$ and was fermented at $15 \pm 2^{\circ} \mathrm{C}$ for 14 days followed by racking, fining and ageing $5 \pm 2^{\circ} \mathrm{C}$ for 30 days. The wine had $10.5 \%$ (v/v) alcohol, residual specific gravity of $5.10 \%$ by weight,
\end{abstract}

$0.71 \%$ tartaric acid and a $\mathrm{pH}$ of 3.5. The wine had a brilliant red colour and blackcurrant like flavour. Sensory evaluation results showed that the wine was significantly $(p<0.05)$ comparable to some bottled imported red wines. This was corroborated by $68 \%$ of assessed consumers who indicated their willingness to buy the wine if it was offered for sale.

Key Words Red wine, pawpaw, palm wine yeast, must, roselle calyces extract.

\section{INTRODUCTION}

$M^{\infty}$ ost red wines consumed in Nigeria are completely fermented, aged bottled imported wines. The temperature restriction of grape to the temperate regions predisposes this trend. However, the very high duty on imported wines has stimulated interest in producing wines from tropical fruits. Although fruit wines have been produced from mango, pineapple and orange fruits (Amerine et al 1980) and less known tropical fruit like pawpaw (Obayenju Ademokeya, 1991). These wines predominantly had poor colour and are priced lower than the imported white and red wines.

Generally, typical red wines have not been produced from tropical fruits because of their low content of extractable red pigments as red varietal grapes. Efforts towards producing red wine by adding synthetic red colourants or dyes are usually controlled, as their use and quantities are regulated by law to prevent toxicity in humans. (USFDA, 1993).

However, a tropical fruit with potential for producing red wines is the Roselle (Red or Indian Sorrel), Hibiscus sabdariffa Var Sabdariffa. The red variety of Roselle has bright red juicy calyces (Tindall, 1986), and according to Kochhar (1986), hot water extracts of these fleshy calyces are used in making "cacody tea" and fermented drinks in Egypt, while Gibbon and Pain (1985), reported that 
the calyces are boiled with sugar to produce karkade drink in Sudan and zoborodo in Nigeria. Since the hot water extracts of these calyces have a history of human consumption, producing wine from this extract or in combination with other tropical fruit juices maybe feasible.

The production of red wine with all its raw materials sourced locally implied using yeast locally sourced too. Generally, all wines are produced using wine yeast-Saccharomyces cerevisiae var, ellipsoideus (Amarine et al 1980), which is also imported. However, Obisanya et al (1987) and Somiari et al (1993), have shown that palm wine yeast sacchromyces cerevisiae has the potential of wine yeast and it is also alcohol tolerant.

Although, the procedure of wine production is well documented (Amerine et al, 1980), the aim of this work is to produce red wine with all its raw materials sourced from the tropics by adopting the established wine production procedure and to compare the quality of the wine with that of imported and local red wine brands currently in Nigerian market.

\section{MATERIALS AND METHODS Pawpaw}

Pawpaw (Carica papaya) must was prepared from ripe fruit (mixed varieties) obtained from the Prison centre farm, Ibite Olo, Nigeria. Mature sundried roselle calyces (Hibiscus sabdriffa) were bought from Baban Kasua market in Bauchi, Nigeria. The palm wine was obtained from $\mathrm{NgO}-$ Owo farm, Udi near Enugu, Nigeria.

Preparation of the roselle calyces extracts

The sun-dried calyces were sorted, washed (rapidly in cold water and extracted with hot water at $80^{\circ} \mathrm{C}$ in batches. Ten gram per batch of the calyces were soaked and stirred in $80 \mathrm{ml}$ hot water for $10 \mathrm{~min}$. This was then filtered and the residual calyces were further re-extracted twice with $10 \mathrm{ml}$ each of hot water. The filtrate and the two rinse water extracts were blended to give $10 \%(\mathrm{w} / \mathrm{v})$ roselle calyces hot water extract (RWE).

\section{Must preparation}

The ripe pawpaw fruits were washed, peeled and macerated at 300 Watt for 25 min with Ken Wood blender (Model, Kw, 10, United Kingdom).

The juice was strained through a nylon sieve $(0.8 \mathrm{~mm})$ and standardized by adding granulated sucrose (England, UK) to raise its specific gravity from $7 \%$ to $20 \%$ (w/w) brix. The juice was mixed with the roselle hot water extract at the ratio of 1:3, and $1 \%(\mathrm{w} / \mathrm{w})$ of milled casein (Bauchi, Nigeria) was added. The must was then pasteurized at $68^{\circ} \mathrm{C}$ for $15 \mathrm{~min}$ and cooled to $23 \pm 2^{\circ} \mathrm{C}$.

\section{Isolation and propagation of palmwine yeast}

Yeast was isolated from 24h-old palmwine using the modified method of Olurunfemi et al (2005). One $\mathrm{ml}$ of the palmwine was diluted with $10 \mathrm{ml}$ of sterile water and agitated for even distribution. One ml of the solution was cultured on acidified ( $\mathrm{pH} 4.0)$ Malt Extract Agar (MEA) and incubated at $37 \pm 1^{\circ} \mathrm{C}$ for $24 \mathrm{~h}$. The identified yeast colonies were further sub-cultured using acidified ( $\mathrm{pH}$ 4.0) (MEA) to obtain pure strain of Saccharomyces cerevisiae. This was confirmed by carrying out sugar fermentation test using maltose, (M) sucrose (S) and glucose (G). The medium was prepared with the composition of $1.0 \%$ peptone, $0.1 \%$ sodium chloride and $1.0 \%$ each of the fermentable sugar. The confirmed $(\mathrm{M}+, \mathrm{S}+$, $\mathrm{G}+$ ) yeast was then grown on acidified MEA slant and stored at $37 \pm 1^{\circ} \mathrm{C}$ as the stock culture.

The propagation involved transferring stock cultures from four acidified MEA slants into $200 \mathrm{ml}$ standard must in an elenmeyer flask mounted on an orbital shaker (Prolabo Oscil 12, France) for 24h and subsequently topped with $200 \mathrm{ml}$ portions of the standard must after $48 \mathrm{~h}$ and $72 \mathrm{~h}$ respectively. The yeast had $98 \pm 2 \%$ viability and an initial viable cell count of 5 to $10 \times 10^{6}$ cells per $\mathrm{ml}$.

\section{Fermentation}

Ten litres of the standard must were pitched with $800 \mathrm{ml}$ of the propagated yeast to give a pitching 
rate of $8 \%(\mathrm{v} / \mathrm{v})$ and fermented in a 12 litre glass jar at $15 \pm 2^{\circ} \mathrm{C}$ for 14 days. The wine was racked, fined with $1 \%$ gelatine (England, UK) and aged at $5 \pm 2^{\circ} \mathrm{C}$ for 31 days. The aged wine was filtered through a cheesecloth sieve $(0.002 \mathrm{~mm})$, and bottled.

\section{Chemical analysis}

The titrable acidity, $\mathrm{pH}$ and specific gravity of the pawpaw juice, roselle calyces hot water extract and the standardized must were determined by the method of AOAC (2000). Alcohol percent of the fermenting must were determined every $24 \mathrm{~h}$ for the first 8 days and every $48 \mathrm{~h}$ for the subsequent 6 days. These parameters were also determined for the produced wine and the imported wine.

The titratable acidity was determined according to the method of Zoecklein et al; (1990) and reported as tataric acid (\%,w/w). The soluble solids was determined using Abbe's refractometer Soplem 272,700 , France at $20^{\circ} \mathrm{C}$, while the alcohol concentration was determined using the alcohol distillation and specific gravity method (Egan et al; 1987) and conversion table (Amerine, et al; 1980).

\section{Sensory evaluation}

The bottled wine samples were evaluated for colour, taste and general acceptability rating by a panel of 20 randomly selected men and women of between 18-40 years of age, who are familiar with testing wines. Each assessor was presented with chilled $\left(15 \pm 2^{\circ} \mathrm{C}\right)$ coded samples of wine in a clear glass tumbler and asked to taste the samples and rate their impression on a 9-point hedonic scale from excellent (9) to extremely bad (1). Two fully fermented imported red wines and one red wine made in Nigeria were used as comparative references samples. The coded developed wine samples were also separately presented to the respective assessors to indicate if they would buy the wine if it were presented for sale.

\section{Statistical analysis}

The data were analysed for variance using the Duncan multiple range test (Duncan, 1955) to locate differences among sample means at 5\% level of significance.

\section{RESULTS AND DISCUSSION}

The must had chemical characteristics (Table 1) that compared well with grape must (Amerine et al; 1980); although its specific gravity was augmented with granulated sucrose. The $\mathrm{pH}$ of the Roselle extract $\mathrm{pH}$ (2.34) was adjusted to the desired $\mathrm{pH}$ of the must ( $\mathrm{pH} 3.76)$ by blending it with the pawpaw juice ( $\mathrm{pH} 4.34)$. The attained must ( $\mathrm{pH}$ 3.76) falls within the $\mathrm{pH}$ level of $3.5-4.0$ that was reported to be optimal for palmwine yeast activity (Somari et al,1993).

However, the higher tartaric acid level $(0.71 \%)$ of the product when compared to that of the imported wine brands $(0.51 \%)$ could be due to the initial low $\mathrm{pH}$ of the Roselle extract ( $\mathrm{pH} 2.34)$. This is consistent with the reported high residual total acidity of roselle water extract by Udom et al (2001). However, this $(0.71 \%)$ falls within the level acceptable for wines (Zoeklein, et al;1990 and Akoma, et al; 2001).

The observed reduction in specific gravity from $22 \%$ to $5.0 \%$ and the resultant increase in the alcohol concentration from 0 to $10.5(\%, \mathrm{v} / \mathrm{v})$ with fermentation shows the efficiency of the Saccharomyces cerevisiae isolated from palm wine. Its attenuation at between 10.0 to $10.5(\%, \mathrm{v} / \mathrm{v})$ alcohols implies that the yeasts is alcohol tolerant (Zoecklein et al; 1990). The observed low variation in $\mathrm{pH}$ and titratable acidity (Table 2) underscores the ability of pure strain of Saccharomyces cerevisiae from palm wine yeast to yield alcohol at acceptable levels in fruit wine production without objectionable high acidity.

The high yield of alcohol is attributed to the ability of palmwine yeast to break down the fermentable sugars in the must. This characteristics of palmwine yeast has been effectively employed in the production of wine from mango must by Somari 
et al (1993) and in leavening of dough by Olorunfemi et al (2005).

The sensory quality attributes of the wine were highly rated as shown from the mean scores of the assessors (Table 3) for colour (7.09), taste (7.55) and general acceptability (7.14) which were significantly $(\mathrm{p}<0.05)$ better than or comparable to the reference imported red wine brands that had average rating scores for colour, taste and general acceptability varying from 5.64 to $7.32,5.41$ to 6.96 and 5.27 to 7.14 respectively. This is corroborated by $68 \%$ of the assessors who indicated their willingness to buy the wine if it was offered for sale. The bright red colour of the wine (Table 3) resulted from the extraction of the predominantly red pigments of the Roselle calyces into the wine. The work of Udom et al (2001) confirmed that the red pigment in Roselle calyces is predominantly anthocyanins

The acceptably higher mean scores for taste and flavour by the taste panel for the developed red wine could be due to the peculiar black currant-like flavour of the roselle extract (Kochhar, 1986) and or fermentation with pure culture of $S$. cerevisiae from palm wine. Unlike wines produced using other fruit and fermented with palm wine yeast that had mild palm wine taste (Obayanju et al, 1991 and Obisanya et al, 1987), this wine was reported by the assessors to have black currant-like flavour with marked absence of palm wine taste.

\section{CONCLUSION}

An acceptable tropically sourced red wine can be produced from the combined use of ripe pawpaw fruit juice, extract from mature red roselle calyces and pure culture of $S$. cerevisiae obtained from palm wine. The procedure if adopted and upgraded can be virtually used in both cottage and industrial brewing of red wine as the roselle plant grows and produces well as a tropical plant. Roselle extract could therefore serve as a veritable source of red colourant for wines produced in the tropics, where grapes do not grow.

\section{REFERENCES}

Akoma, O.; Onuoha, S. O; and Ozigis, A. A. (2001): Physico-chemical attributes of wine produced from the yellow pulp of parkia biglobosa Nigerian Food Journal Vol 19, 76 - 79.

Amerine, M. A. Berg, H. W. Kunkee, R. E Ough, C. S. Singleton, V. L and Webb, A. C. (1980). The Technology of Wine Making ( $4^{\text {th }}$ edition). Avi Publishing Co., Inc. Westport, C. T. U. S. A., p359380

AOAC (2000). Official methods of Analysis of Association of Analytical Chemist (AOAC) International, $17^{\text {th }}$ edition Horowitz (ed) Vol $1 \& 2$ 45: 12 - 20

Duncan, D. B. (1955). Multiple ranges and Multiple F-tests. Biometrics 11, 1-42.

Egan, H., Kirk, R. S. and Sawyer, R. (1987). Pearson's Chemical Analysis of Foods ( $8^{\text {th }}$ edition) p347-352. Longman Scientific and Chemical Publishers., Edinburgh; Churchill, Livingstone.

Gibbon, D. and Pain, A. (1985). Crops of the Drier Regions of the Tropics ( $1^{\text {st }}$ edition) p 61-62. English Language Book Society/Longman, England.

Kochhar, S. L. (1986). Tropical Crops: a textbook of economic botany. ( $2^{\text {nd }}$ edition) p 40-41 Macmillan Publishers, Ltd., London, U. K.

Obayanju, V. S. and Ademokeya, A. A. (1991) Utilization of pawpaw juice for wine making. Nigeria Journal of Technical Education 8, 125-128.

Obisanya, M. O., Aina, J. O. and Oguntimehin G. B. (1987): Production of wine from Mango using Saccharomyces and Schizosaccharomyces spp isolated from palm wine. Journal of Applied Bacteriology Vol 63, 191 - 196. 
Olorunfemi, O. B. and Adetuyi, F. C. (2005): Isolation of baking yeast from naturally fermented pineapple. Journal of Food, Agriculture and Environment Vol. 3(1): 115 - 117.

Somari, R. I. and Udo, A. E. (1993): Evaluation of the performance of yeast isolated from sap of Elaeis guineensis in dough leavening. Nigerian Food Journal Vol 11: $34-44$

Tindall, H. D. (1986). Vegetables in the Tropics (1 ${ }^{\text {st }}$ edition). EnglishLanguage Book Society/Macmillan London, U.K, p 332-334.

Udom, O. O.; Igwe, C. C. and Oshinowo F. A. O. (2001): Comparison of the Anthocyanin content of two varieties of Red Roselle (Hibiscus saddariffa) from Nigerian Food Journal, Vol. 19: 101 - 106.

USA, Food and Drug Administration (1993): FDA/ CFSAN Brochure on Food colour facts. (www.cfsan.fda.gov/ Ird/colour fac.html)

Zoecklein, B. W.; Fugelsang, K. C.; Cump, B. H. and Nurry, F. S. (1990): Production Wine Analysis ( $1^{\text {st }}$ edition) Avi Publication Co. Inc, Westport, Connecticut p $71-243$.

Table 1: Chemical characteristics of pawpaw juice, roselle extract, must, wine (product) and imported wine brands.*

\begin{tabular}{|l|l|l|l|l|l|}
\hline Parameter & $\begin{array}{l}\text { Pawpaw } \\
\text { juice }\end{array}$ & $\begin{array}{l}\text { Roselle } \\
\text { extract }\end{array}$ & Must & $\begin{array}{l}\text { Product } \\
\text { (wine) }\end{array}$ & $\begin{array}{l}\text { Imported } \\
\text { brands }\end{array}$ \\
\hline $\mathrm{pH}$ & $4.34 \pm 0.20$ & $2.34 \pm 0.14$ & $3.76 \pm 0.08$ & $3.57 \pm 0.02$ & $3.54 \pm 0.22$ \\
\hline$\%$ Brix & $7.00 \pm 0.90$ & $2.50 \pm 0.02$ & $22.00 \pm 0.20$ & $5.10 \pm 0.01$ & $6.57 \pm 1.75$ \\
\hline $\begin{array}{l}\text { TA (\% Tartaric } \\
\text { acid })\end{array}$ & $0.15 \pm 0.07$ & $0.67 \pm 0.01$ & $0.56 \pm 0.08$ & $0.71 \pm 0.04$ & $0.51 \pm 0.10$ \\
\hline $\begin{array}{l}\% \text { alcohol } \\
(\mathrm{v} / \mathrm{v})\end{array}$ & 0 & 0 & 0 & $10.50 \pm 0.01$ & $8.75 \pm 2.25$ \\
\hline $\begin{array}{l}\text { Colour } \\
(\text { visual })\end{array}$ & $\begin{array}{l}\text { Light } \\
\text { yellow }\end{array}$ & Deep red & Dull red & $\begin{array}{l}\text { Brilliant } \\
\text { Red }\end{array}$ & $\begin{array}{l}\text { Rose to . } \\
\text { Red hue }\end{array}$ \\
\hline
\end{tabular}

*Values are means of 3 treatments \pm standard deviation. 
Production of red wine from roselle pawpaw using palm wine yeast......

Okoro, C.E.

Table 2: Changes in $\mathrm{pH}$, titrable acidity, specific gravity and alcohol concentration during fermentation.*

\begin{tabular}{|c|c|c|c|c|}
\hline Day & $\begin{array}{l}\text { Specific gravity } \\
{ }^{\circ} \text { Brix \% (w/w) }\end{array}$ & $\begin{array}{l}\text { Alcohol } \\
(\% \mathrm{v} / \mathrm{v})\end{array}$ & pH & $\begin{array}{l}\text { Titrable acidity as } \\
\text { tartaric acid ( } \% \text { w/w) }\end{array}$ \\
\hline 0 & $22.1 \pm 0.20$ & & $3.76 \pm 0.08$ & $0.56 \pm 0.08$ \\
\hline 1 & $20.5 \pm 0.11$ & $1.5 \pm 0.02$ & $3.75 \pm 0.02$ & $0.56 \pm 0.08$ \\
\hline 2 & $17.5 \pm 0.14$ & $2.5 \pm 0.01$ & $3.73 \pm 0.02$ & $0.59 \pm 0.06$ \\
\hline 3 & $14.9 \pm 0.20$ & $3.0 \pm 0.01$ & $3.71 \pm 0.01$ & $0.62 \pm 0.04$ \\
\hline 4 & $13.7 \pm 0.18$ & $4.5 \pm 0.03$ & $3.70 \pm 0.01$ & $0.63 \pm 0.03$ \\
\hline 5 & $12.6 \pm 0.15$ & $6.0 \pm 0.15$ & $3.68 \pm 0.02$ & $0.64 \pm 0.01$ \\
\hline 6 & $11.1 \pm 0.21$ & $7.5 \pm 0.05$ & $3.67 \pm 0.01$ & $0.66 \pm 0.01$ \\
\hline 7 & $10.2 \pm 0.11$ & $8.5 \pm 0.07$ & $3.65 \pm 0.03$ & $0.67 \pm 0.01$ \\
\hline 8 & $9.3 \pm 0.15$ & $9.5 \pm 0.01$ & $3.65 \pm 0.03$ & $0.68 \pm 0.01$ \\
\hline 10 & $8.8 \pm 0.12$ & $9.5 \pm 0.01$ & $3.64 \pm 0.01$ & $0.68 \pm 0.03$ \\
\hline 12 & $8.2 \pm 0.16$ & $9.5 \pm 0.01$ & $3.62 \pm 0.01$ & $0.69 \pm 0.04$ \\
\hline 14 & $7.2 \pm 0.09$ & $10.0 \pm 0.02$ & $3.61 \pm 0.01$ & $0.70 \pm 0.06$ \\
\hline $\begin{array}{l}\text { After } \\
\text { ageing } \\
\text { (30 days) }\end{array}$ & $5.1 \pm 0.01$ & $10.5 \pm 0.01$ & $3.57 \pm 0.02$ & $0.71 \pm 0.04$ \\
\hline
\end{tabular}

*Values are means of 3 samples. 
Table 3: Sensory attributes of wines*

Means scores attributes of wines

\begin{tabular}{lrrrr} 
Attributes & $*$ RRW & TOW & YSW & CRW \\
\hline Colour & $7.09 \pm 0.97 \mathrm{a}$ & $5.59 \pm 1.79 \mathrm{~b}$ & $7.32 \pm 1.49 \mathrm{a}$ & $5.64 \pm 1.24 \mathrm{~b}$ \\
Taste & $7.55 \pm 0.74 \mathrm{c}$ & $6.00 \pm 1.50 \mathrm{~d}$ & $6.96 \pm 1.43 \mathrm{c}$ & $5.41 \pm 1.56 \mathrm{~d}$ \\
Flavour & $6.64 \pm 1.16 \mathrm{e}$ & $6.00 \pm 1.39 \mathrm{e}$ & $6.5 \pm 0.98 \mathrm{e}$ & $5.73 \pm 1.39 \mathrm{e}$ \\
General & & & & \\
Acceptability & $7.14 \pm 0.99$ & $6.05 \pm 1.9 \mathrm{bg}$ & $7.14 \pm 1.49$ & $5.27 \pm 1.83 \mathrm{~g}$
\end{tabular}

*Sample means with the same alphabets attached along the rows are not significantly different from each other at $5 \%$ levels.

Table 4: Sample code descriptions

\begin{tabular}{llll} 
Code & \multicolumn{1}{c}{ Brand } & \multicolumn{1}{c}{ Colour } & Country of production \\
\hline RRW & The developed product & Bright deep red & Nigeria \\
TQW & Torres de quart & Bright light rose & Spain \\
YSW & Yago Santyago & Bright deep red & Spain \\
CRW & Concord Red Wine & Dull deep red & Nigeria \\
\hline
\end{tabular}

